
YIl 16
Bahar 2018
Sayı 24
Ss. 15-27

Geliş Tarihi: 19.01.2018

Kabul Tarihi: 26.03.2018

\title{
Bir Ütopyacı İtkinin Yansımaları: Sait Faik Abasıyanık'ın Edebi Eserlerinde Ütopya
}

\author{
Bilgin Güngör*
}

$\ddot{O} z$

Sosyolojik açıdan insan, toplumsal düzenin koşullamasıyla somutluk kazanmakla birlikte yeni toplumsal düzenin oluşmasında da en etkin unsur olarak öne çıkar; çünkü insan, toplumsal bir varlık olarak, içerisinde bulunduğu şartlardan ve kazandiğl tecrübelerden hareketle yeni bir toplumsal düzen planlamasl yapabilir. Nitekim bugünkü modern toplum düzenini bir yönüyle Rönesans, bir yönüyle de Aydınlanma Çağl düşünürlerinin eserlerinde dolayl veya dolaysız bir şekilde çizilen tasavvurlara borçlu olduğumuz ortadadır. Fakat bazen söz konusu tasavvurlar, gerçeklik sinırının ötesinde somutluk kazanır. Işste bu noktada ütopik bir tasavvur ortaya çıkar. Oluşturulması arzu edilen toplumsal düzenin salt fikir düzeyinde kaldığ beri mevcuttur. Fakat ütopyanın net ve bugün anladığımız biçimde ortaya çıkışı, 16. yüzyılda Thomas More'un Ütopya 'sılla başlar; 20. yüzyılda ise distopyaların ortaya çıkışıyla ütopik metinler, hiç olmadığı kadar çeşitlilik arz edecek noktaya gelir. Bu incelememizde modern Türk edebiyatında Çehov tarzı hikâyeciliğin öncülerinden olan Sait Faik Abasıyanık'ın eserlerinde çoğunlukla örtük bir şekilde çıkan ütopik unsurlara yoğunlaşılacak ve onun ütopyacı itkiyi aşmayan mutlu gelecek tasavvuru sebepleriyle betimlenmeye çallşılacaktır.

Anahtar Kelimeler: Sait Faik Abasıyanı, ütopya, ütopyacı itki, ütopyacı program, hikâye, roman, şiir...

\section{Reflections of an Utopian İmpulse: Utopia in Sait Faik Abasıyanı's Literary Works}

\section{Abstract}

From a sociological point of view, human beings become the most effective element in the formation of a new social order as well as concretization through the conditioning of social order; because human beings can plan a new social order as a social being, acting on the basis

* Yrd. Doç. Dr., Çanakkale Onsekiz Mart Üniversitesi, Fen-Edebiyat Fakültesi, Türk Dili ve Edebiyatı Bölümü, bilgingungor@comu.edu.tr 
of their conditions and experience. As a matter of fact, we are owed to the modern social order of today in a way towards the Renaissance, and in a way, the ideas which are drawn directly or indirectly in the works of the Enlightenment thinkers. But sometimes the contemplative ones become concrete beyond the limits of reality. At this point a utopian conception emerges. These kinds of imaginings, which the formation of the desirable social order to be formed remain purely at the level of ideas, have existed since the beginning of history. But the emergence of the utopian in a clear and understood form today begins with the Utopia of Thomas More in the 16 th century; In the 20th century, with the emergence of dystopias, utopian texts come to the point where they will be as diverse as ever. In this review we will concentrate on the utopian elements that are mostly implicit in the works of Sait Faik, one of the forerunners of Chekhov-style storytelling in modern Turkish literature, and try to be portrayed with the reasons of happy future contemplation that does not exceed his utopian impulse.

Key Words: Sait Faik Abasıyanı, utopia, utopian impulse, utopian program, story, novel, poem... 


\section{GíRiș}

Toplumsal kurumlar ve kurallar gibi insan da, öz olarak, tarihsel bir süreç içerisinde değişimden nasibini alan ve buna bağlı olarak her dönemde yeni -veya idealportresi çizilen toplumsal bir varlıktır. Bu husus en açık ifadesini, Karl Marx'ın Critique of Hegel's Right Philosopy (Hegel'in Hukuk Felsefesinin Eleştirisi) adlı eserinde bulur. Marx, söz konusu eserde "the human essence has no true reality" ("insan özünün herhangi bir gerçekliği yoktur”) yargısına varır ve insan özünün sabit bir gerçeklikten çok değişken bir gerçekliğe sahip bulunduğunu, bu gerçekliğin toplumsal ilişkiler tarafından belirlendiğini, dolayısıyla da insanın -kendi devrindeki- toplumsal ilişkilerin bir ürünü olduğunu belirtir. ${ }^{2}$ Fakat buradaki ilişki tek yönlü değildir. Kendi dönemindeki toplumsal ilişkilerin bir ürünü olan insan, zaman zaman, özellikle de Fransız sosyolog Emile Durkheim'ın $a n o m i^{3}$ adını verdiği düzensizlik durumunda, yeni bir toplumsal ilişki ağına sahip yeni bir dünya arayışına girerek sanat, felsefe, bilim gibi söylem alanlarında bu yeni dünyanın resimlerini çizmeye başlar; bu resimlerin bir kısmı somutlaşsa da bir kısmı gerçeklik sınırlarını zorlar ve böylelikle de ütopya meydana çıkar.

Ütopyalar, tarihsel açıdan, Orhan Hançerlioğlu'nun Düşünce Tarihi adlı eserinde ele aldığı "altınçağ" özlemine ${ }^{4}$ zemin hazırlayan toplumsal yapıya yönelik bir aksülamel olarak, medeniyetin doğumuna paralel ortaya çıktığı bilinen düşüncelerden kaynağını bulsa da gerçek anlamda somutlanışı, Ortaçağ'dan yeni yeni kurtulan ve modern dünyanın kuruluşunun arifesinde bulunan Rönesans insanının geleceğe yönelik tasavvurlariyla vuku bulur. Thomas More'un Ütopya, Tommaso Campanella'nın Güneş Ülkesi gibi eserleri, Rönesans insanının, Ortaçağ'ın din merkezli yapısının akıl ve insan merkezli yeni bir yapıya evrilmeye başladığı, Max Weber'in deyişiyle rasyonalleşmişs ${ }^{5}$ Avrupa toplumlarına yönelik o dönemki gelecek tasavvurlarıdır. ${ }^{6}$

Fakat ilerleyen dönemlerde, özellikle de Sanayi Devrimi sonrasında ortaya ç1kan bazı gelişmeler (eşitsizliğin giderek artması, insanların ağır hak ihlallerine maruz bırakılması, çalışma saatlerindeki artış vs.) bu gelecek tasavvurlarının gerçekçiliğin sorgulanmasına yol açar ve 20. yüzyılın başlarına gelindiğinde de bir aksülamel yaratır. İki dünya savaşını ve kıtlığı gören, Theodor Adorno ve Max Horkheimer'in

\footnotetext{
Karl Marx-Fredrich Engels, Collected Works, Vol. 3, Lawrance and Wishart, London 1975. p. 175. ve yazarları, önce Yeni Zellanda, sonrasında ise Manisa'da komünal bir hayat biçimini somutlaştırmaya çalışırlar. Özellikle Tevfik Fikret'in "Ömr-i Muhayyel”, "Yeşilyurt” gibi şiirleri, bu bakımdan önemlidir.
} 
özgül terminolojisinden hareketle söylersek aydınlanmanın özyıkımına ${ }^{7}$ şahit olan bu yüzyılın umutsuz insanı, ütopyalar karşısında büyük oranda inançlarını yitirir ve "karş1-ütopya" anlamına gelen distopyaları üretmeye başlar. Aldous Huxley'in Brave New World'ü (Cesur Yeni Dünya) ile George Orwell'ın 1984'ü, 20. yüzyllın toplumsal ilişkilerinin etkisiyle benlik kazanan insanın, geleceğe yönelik ortaya koyduğu umutsuz tablo taslakları olarak en ünlü distopyalar arasında yer alır. Bu distopyaların her biri, gelecekte tiranlıkların egemen olacağı, bütün kitle iletişim araçlarının -Louis Althusser'in ünlü kavramından hareketle ifade edersek- "devletin en şiddetli ideolojik aygitları" ${ }^{\prime \prime}$ olarak bu egemenliğe ortam oluşturacağ 1 ve tek tip insanlardan mürekkep "kapalı toplum"ların bulunacağı bir dünyanın resmini çizer. Fakat aynı yüzyılda, umudunu yitirmeyen ve belli belirsiz bir ütopyanın ardından yürüyenlerin da mevcut olduğunu görebilmek mümkündür. Bu durum özellikle, gelecekteki sınıfsız, özgür ve insani bir toplum yaratma ideali peşinde yürüyen sosyalist sanatçılar (Pablo Neruda, Nâzım Hikmet, Louis Aragon) ve düşünürler (Jean-Paul Sartre, Herbert Marcuse) göz önünde bulundurulduğunda bir anlam ifade eder.

$\mathrm{Bu}$ noktada eklemek gerekir ki ütopyalar, onların "her zaman siyasi bir mesele"9 olduğunu düşünen ABD'li eleştirmen Fredric Jameson'ın da vurguladığı gibi, mahiyeti itibariyle iki şekilde kurgulaştırılır. Illk şekilde ütopya, kurgusal açıdan belli ilkeleriyle ve sınırları açık bir şekilde çizilmiş konumda ortaya çıkarak ütopik kurgunun malzemesi olur. İște bu tür ütopik kurgulara Jameson, ütopyacı program adını verir. ${ }^{10}$ More'un Ütopya'sı, Campanella'nın Güneş Ülkesi bu tür ütopik kurguların en belirgin örnekleri arasındadır; bunlarda ütopik ülke veya hayat bütün özellikleriyle birlikte net bir şekilde verilir. İkinci şekilde ütopya, içerisinde bulunduğu kurgunun temel bileşeni olmamakla ve görece belirsiz bir biçimde somutlaşma imkânı bulmakla birlikte metnin geleceğe dönük tasavvurları içeren örtük bir cephesini oluşturur. $\mathrm{Bu}$ sınırları belirsiz, görece kapalı ütopik kurgu türü sadece gizil bir itki hâlinde mevcut olduğu için Jameson tarafından ütopyacı itki ${ }^{1 l}$ olarak adlandırılır. Maksim Gorki'nin Ana romanı veya Nâzım Hikmet'in Benerci Kendini Niçin Öldürdü? şiiri, çerçevesi tam bir şekilde çizilmiş olmasa da yer yer alımlanabilen ve sosyalizme dönük olarak beliren "mutlu gelecek zaman" tasavvurunu barındırmaları sebebiyle, ütopyacı itki şeklindeki kurgunun somutlaştığı eserlere birer örnek teşkil eder.

7 Theodor W. Adorno-Max Horkheimer, Aydınlanmanın Diyalektiği, Çev. Nihat Ülner-Elif Öztarhan Karadoğan, Kabalcı Yayınları, İstanbul 2000. s. 126.

8 Fransız düşünür Althusser, Gramsci'nin “hegemonya" kuramından hareketle devletin iki yönlü bir mekanizmaya sahip olduğunu, ilk yönünde ideolojik aygıtların, ikinci yönünde ise baskı aygıtlarının bulunduğunu belirtir. İdeolojik aygıtlar, devleti yöneten sınıfın ideolojisini yeniden üretir; okul, televizyon, gazete vs gibi unsurlar bu aygıtlar içerisinde değerlendirilir. Baskı aygıtları ise egemen sınıfların hâkimiyetini sağlama işlevine sahip bulunan güvenlik kurumları olarak konumlandırılır. Bkz. Louis Althusser, İdeoloji ve Devletin İdeolojik Aygıtları, Çev. Alp Tümertekin, İthaki Yayınları, İstanbul 2014. s. 56-57.

9 Fredric Jameson, Ütopya Denen Arzu, Çev. Ferit Burak Aydar, Metis Yayınları, İstanbul 2009, s.9.

10 Ütopya Denen Arzu, s. 20.

11 Ütopya Denen Arzu, s. 20. 
Bir sosyalist olmamakla, hatta herhangi bir belirgin siyasi tutumu bulunmamakla $^{12}$ birlikte modern Türk edebiyatının önde gelen hikâyecisi Sait Faik Abasıyanık da bu yüzyılın umutlu insanlarından/aydınlarından birisi olarak, edebi eserlerinin estetik düzleminde insana ve hayata yönelik iyimserliğini dile getirir ki bu iyimserlik, zaman zaman, yeni toplumsal ilişkilerin var olduğu ve bu ilişkilerin yarattığı mutlu insanın merkez alındığı, fakat sınırlarının tam manasıyla çizilmediği, belirginlikten görece uzak bir ütopyacı itkiye doğru gider. Bir başka deyişle, Jameson'ın en faşist yazarların dahi eserlerinde belirtik ya da örtük hâlde bulduğu eşitlikçi toplum hayali ${ }^{13}$, Sait Faik'te zaman zaman ütopyacı itki şeklinde ortaya çıkar.

Bu incelemede, Sait Faik'in edebi eserlerinde öne çıkan ütopik dünyayı; bir başka deyişle, onun romanlarının ve hikâyelerinin kurgusunda beliren ütopyacı itkinin izlerini ele alacağız.

\section{Sait Faik'in Ütopyasının Belli Başlı Hususiyetleri}

Çehov tarzında ve sade bir üslupla kaleme aldığı eserlerinde, Ahmet Hamdi Tanpınar'ın da belirttiği gibi şehir ve ada hayatındaki insanın dünyasını işleyen ${ }^{14}$ Sait Faik'te yer yer beliren ütopik dünya, belli başlı hususiyetler etrafinda teşekkül eder. "Insansız hiçbir şeyin güzelliği yok. Her şey onun sayesinde, onunla güzel"15 diyen Sait Faik' in ütopyasındaki bu hususiyetler arasında ilk bahsetmemiz gereken, insanların zengin-fakir ayrımı içerisinde ögütülmeden, eşitlikçiliğin mührünü vurduğu toplumsal ilişkiler çerçevesinde mutlu bir şekilde yaşaması prensibidir. Bu prensip, en net şekilde, 1951 senesinde yayımlanan ve birbirlerine kurgusal olarak bağlı bir dizi hikâyeyi içeren Havada Bulut kitabındaki iki aylak arkadaşın başından geçenlerin konu alındığı "Ay Işığı” hikâyesinde görülür. Söz konusu hikâyedeki aylaklardan birisinin iş başvurusu için gittiği gazetede karşılaştığ 1 durumlarda ve özellikle de başmuharrirle girdiği diyalogda, Sait Faik'in ütopyasının söz konusu hususiyeti ortaya çıkar:

"En son bir gazeteye müracaat ettim. Başmuharrir cenaplarının karşıstna çıktık. Siyasi kanaatlerimi sordu. Olmadı̆̆ını söyledim. Hiç düşünmediğim şeyi bana soruyordu. Ne mebus olmak, ne de gazetede siyasi yazılar yazmak niyetindeydim. Röportajlar yapmak, muhabirlik etmek için siyasi kanaatimin ne faydası vardı? Ben insanlar ve kendim hakkında düşünürüm. Hükümetler hakkında, rejimler hususunda hiçbir fikrim yoktu.

Başmuharrir ağız aramakta ustaydl:

12 Nitekim Sait Faik, Yaşar Kemal ile yaptığı 17 Mayıs 1953 tarihli söyleşisinde siyasetle ilgilenmediğini sezdirir. Bu röpotaj hakkında bilgi için bkz. Zülfü Livaneli, Gözüyle Kartal Avlayan Yazar: Yaşar Kemal, Doğan Kitap, İstanbul 2016. s. 211.

13 Fredric Jameson, Modernizm İdeolojisi: Edebiyat Yazılarl, Çev. Kemal Atakay-Tuncay Birkan, Metis Yayınları, İstanbul 2008. s. 24.

14 Ahmet Hamdi Tanpınar, "Türk Edebiyatında Cereyanlar", Edebiyat Üzerine Makaleler, Haz. Zeynep Kerman, Dergâh Yayınları, İstanbul 1990. s. 123.

15 Sait Faik Abasıyanık, Son Kuşlar, Türkiye İş Bankası Kültür Yayınları, İstanbul 2015. s. 29. 
-Yani nasll bir dünya arzuluyorsunuz?

-Nasıl bir dünya mı? Haksıllkkların olmadiğı bir dünya... Insanların hepsinin mesut olduğu, hiç olmazsa iş bulduğu, doyduğu bir dünya... Hırsızlıkların, başkalarının hakkına tecavüz etmelerin bol bol bulunmadiğı... Pardon efendim! Bol bol bulunmadı̆̆ı ne demek? Hiç bulunmadiğı bir dünya...

Sevilmeye lâyık küçücük kızların orospu olmadığı, geceleri hacıağaların minicik kızları caddelerden yirmi beş lira pazarlıkla otellere götüremediği, her genç kızın namuslu bir delikanlıyla konuşabildiği, para için namus, ar, haya, hayat, gece, gündüz satılamadığı bir dünya... Muhabbet tellallarının günde otuz lira kazanmadiğı bir dünya... Sokakta sefillerin bulunmadiğı bir dünya... Kafanın, kolun çalışabildiği zaman insanın muhakkak doyabildiği, eğlenebildiği bir dünya... İ̧̧inde iyi şeyler söylemeye, doğru şeyler söylemeye, salahiyetle kivranan adamın, korkmadan ve yanlış tefsir edilmeden bu bir şeyleri söyleyebildiği bir dünya...

Aynen bunları söyleyemedim. Şimdi söylüyorum. "'16

Başmuharrirle olan diyaloğunda anlatıc1-kişinin çizdiği ve her şeyden evvel “insanların iş bulduğu, hiç olmazsa doyduğu" bir hayatı imleyen eşitlikçi ütopik dünya, yazarın 1940 yılında yayımladığı Şahmerdan kitabındaki "Çelme" hikâyesinde de belirir. Bir Anadolu kasabasındaki şube reisinin "tombul hanımı" olan Refika Hanımın dostlarıyla birlikte yaptığg bir kır gezisinin işlendiği bu hikâyede, köylülerin Refika Hanımın erzaklarını yağma ettiği sahne bu hususta önem taşır. Refika Hanım, söz konusu yağma sırasında şaşkınlaşır ve onu bir "kıyamet"e benzetir. Dostu Ayşe Hanımın da "düşünceli bir şekilde" ve "mırıldanarak" onayladığı bu benzetme, şüphesiz, insanlar arasında eşitliğin vuku bulduğu geleceğe yönelik "korkulu” bir düşüncenin örtük bir şekilde somutlaşması olarak okunabilir:

"Şube reisinin tombul hanımı:

-Allahım kıyamet günü de mi böyle olacak, a Ayşe Hanım? Dedi.

Ayşe Hanım düşünceli:

-Zahir... diye mirlldand...,$" 17$

Sait Faik' in 1944'te yayımladığı ve bir adadaki aşk ve “maişet” macerasını kurgulaştırdığı Medarı Maişet Motoru romanın baş-kişilerinden olan Fahri’nin, dostu Fahrettin Asım ile girdiği bir diyalogda ${ }^{18}$ da eşitliğin egemen olduğu bir dünya tasavvurunun izlerini yine net bir şekilde bulabiliriz. Fahrettin Asım, toprak ağalığı eleştirisi üzerinden özel mülkiyeti sorgular ve buradan eşitliğin hüküm sürdüğ̈ geleceği " $B u$ dünya ergeç, hatta benim bile ümit etmediğim şekilde, insanı hayretlere garkedecek

16 Sait Faik Abasıyanık, Havada Bulut, Türkiye İş Bankası Kültür Yayınları, İstanbul 2015. s. 20-21.

17 Sait Faik Abasıyanık, Şahmerdan, Türkiye İş Bankası Kültür Yayınları, İstanbul 2014. s. 17.

18 Romandaki bazı kısımlar gibi bu diyaloglar da devrin sansürüne takılmış ve eserden çıkarılmıştır. Yazarın Fahrettin Asım'1 avare bir tip olarak çizmesi dahi, bu sansüre engel olamamıştır. 
şekilde, düzelecektir"'19 diyerek işaret etmeye girişir. Sonrasında ise şairane bulduğu bu gelecek tasavvurunu net bir şekilde açımlar. Bu açımlamada sadece insanlar arası değil, aynı zamanda bölgeler arası bir eşitliğin de belirmesi dikkat çeker:

“Benim dünyamda boş laflar bitmiştir. Kimse kalkıp, 'şöyleyim, böyleyim, şöyleyiz, böyleyiz, böyle yapacă̆ız' demez. Yapar. Hiç kimse şarapll, av etli, meyveli yemekten sonra çıktı̆̆ gezintide ăgzının kokusunu burnunun dumanını yüzümüze üflemez. Yahut bizimle aynı kötü elbiseleri giyip, aynı cigaraları iriyor görünerek evine saadetler, ocăğnı bin sene tüttürecek erzakl, refahı ylğmaz. Muhabbetler ne ana, ne baba, ne çocuğa matuftur, insanoğluna... Böyle bir dünyanın açı yoktur. Su klyısında serseri değil, şairi gezer. Yozgat'a deniz, İstanbul'a Yozgat gündüzleri karışmıştır. Memleketler şu veya bu avantajından dolayı özlenilmez. Deniz seyretmeye gidilebilir. Çalışmak hesaplıdır. Ekilmeyen yer yoktur. Beyhude ormanlar, beyude göller yoktur. Mevsimler beyhude gelmez. ${ }^{20}$

Yazarın 1950 yılında yayımladığı Mahalle Kahvesi kitabındaki “Uyuz Hastalığı Arkasından Hayal” hikâyesinde kısmen ve iptidai bir eşitlikçi ütopya bulabiliriz. Bir sinema salonu önündeki farklı sınıflara ait insanların resmedildiği hikâyede, hikâyenin baş-kişisi konumunda bulunan bir aylağın sinema salonu girişindeki "uyuzlu"21 bir çocuğa hâli-vakti yerinde insanların yardım etmesini hayal edişinin de ardında, örtük de olsa, eşitlikçi bir dünya özleminin barındığını düşünebiliriz. "Bir kadın bu çocuğu alıp evine götürüyor, uyuz merhemini sürüyor, üç beş gün evinde tutuyor, sonra isterse yine mikrobun kaynadığı sokağa onu tertemiz bıraklyor... ${ }^{22}$ ifadeleriyle betimlenen ve "yalnız hayal"”2 olduğu vurgulanan söz konusu hayal, eşitlikçi bir düzene dönük son derece çekingen bir imleme çabasının sonucu olarak ele alınabilir.

Tam bu hususta belirtilmelidir ki Sait Faik'in ütopyası eşitçiliğiyle, "herkes yeteneklerine göre, herkes ihtiyaçlarına göre" ${ }^{24}$ mottosuyla öne çıkan sosyalist ütopyayı akıllara getirse de iki ütopyanın özdeş olduğunu söylemek mümkün değildir. Öncelikle Sait Faik'in ütopyasında görece belirli bir konumda bulunan eşitlikçi dünya -Michel Foucault'nun kavramlarıyla dile getirirsek- sosyalist bir dünya görüşü çerçevesinde ortaya çıkan makro/mikro iktidarlar ${ }^{25}$ ve bu iktidarları somutlaştıran tahakküm mekanizmaları başta olmak üzere sosyalist toplumun herhangi bir kurumsal yapısını

19 Sait Faik Abasıyanık, Medarı Maişet Motoru, Türkiye İş Bankası Kültür Yayınları, İstanbul 2014. s. 110.

20 A.g.e., s. 111-112.

21 Sait Faik Abasıyanık, Mahalle Kahvesi, Türkiye İş Bankası Kültür Yayınları, İstanbul 2015. s. 19.

22 A.g.e., s.22.

23 A.g.e., s.22.

24 Georges Politzer, Felsefenin Temel İlkeleri, Çev. Erol Esençay, İlya İzmir Yayınevi, İzmir 2008. s. 422.

25 Michel Foucault, Büyük Kapatılma, Çev. I. Ergüden-F.Keskin, Ayrıntı Yayınları, İstanbul 2007. s. 175 . 
içermez. Dolayısıyla Sait Faik'te insanın, J.A.C. Brown tarafindan frustration (engellenme $)^{26}$ ifadesiyle karş1lanan, toplumun belli bir otorite tarafından görece yoğun gözetime/baskıya maruz bırakılmasını imleyen durumla karşı karşıya kaldığı bir gelecek tasavvuru çerçevesinde değerlendirilmesi mümkün değildir.

Sait Faik'in ütopik dünyasında, insanın çevresine, diğer varlıklara, hülasa hayata dönük olumlayıcı bir tutum da içerilir ki buradan, söz konusu ütopik dünyanın bir diğer önemli hususiyetine ulaşılır. Fikret Ürgüp'ün de belirttiği gibi diğer realist hikâyelerinden farklı olarak sürrealist estetiğin doğrultusunda kaleme alınmış ${ }^{27} 1954$ tarihli Alemdağ'da Var Bir Yılan adı altında yayımladığı hikâye kitabı içinde bulunan "Öyle Bir Hikâye"de, söz konusu ütopyanın bu diğer hususiyeti karşımıza çıkar. İstanbul sokaklarında avare şekilde dolaşan bir aylağın başından geçenlerin konu edinildiği hikâyede söz konusu aylağın, Zeyrek yokuşundaki seddin köşesinde uyumakta olan bir köpeğe rastladıktan sonra onunla "sohbet" ederken dile getirdiklerinde, hayattaki her şeye karşı olumlayıcı tutumu önceleyen bir dünya, "dostluklardan, insanlardan ve hayvanlardan ve ağaçlardan ve kuşlardan ve çimenlerden yapıllmış vazife hissiyle çarpan yüreklerle dolu bir âlem" ve buna uygun bir gelecek dönem ahlâkı vardır:

"Sen Zeyrek yokuşunda kuyruksuz, tüysüz, uyuz, soğuktan titreyen bir sokak köpeği, ben Panço'nun arkadaşı, başka hiçbir şey değil, yağmura vurmuş, uykusuz, canı burnunda, yüreği Ağaççileği Sokağı'nda, kafası Bomonti tramvay durağından yüz metre uzakta kirli bir yastıkta bir adamcağızım. Ne yapalım? Günün birinde dostluklardan, insanlardan ve hayvanlardan ve ağaçlardan ve kuşlardan ve çimenlerden yapılmış vazife hissiyle çarpan yüreklerle dolu bir âlemde yaşayacağımızı düsünelim. Bir ahlakımız olacak ki hiçbir kitap yazmadı. Bir ahlakımız, bugün yaptıklarımıza, yapacaklarımıza, düşündüklerimize, düşüneceklerimize hayretler içinde bakan bir ahlakımız. O zaman seninle daha uzun dostluklar edeceğiz patlak göz. O zaman hiç merak etme. Dostum Panco da bana hak verecektir. Kilise ahlakından söz açmayacak. Dostluğun olağanüstü güzelliğini çocuklarına anlatacaktır. "28

Yazarın, "hiçbir kitap"ın yazmadığı ve yanı başında kimsenin "kilise ahlakından söz açmadığı" yeni bir ahlak nizamını vurgulaması, söz konusu ütopyanın, temelini Tanrı sevgisinden çok insan sevgisinden alan bir kurallar bütününü kapsamakta ve dolayısıyla da kutsiyetle meşrulaştırılmamış bir ahlak dünyasını çağrıştırmakta olduğunun bir göstergesi olarak okunabilir. Daha açık bir ifadeyle söylersek Sait Faik’in ütopik dünyasında ahlak kuralları, söz konusu ifadelerden anlaşılacağı üzere, din dışı bir niteliğe sahiptir. Bu da J.A.C. Borwn'un ahlâkın özüne ilişkin düşüncelerini akla getirir. Brown'a göre, her ne kadar meşrulaştırımını dini kaidelerden almış olsa da genel itibariyle ahlakın özü bu kaideler değildir. Nitekim Brown her iki olgunun

26 J.A.C. Brown, Evolution of Society, Watts \& Co., London, 1946. s. 123.

27 Fikret Ürgüp, "Sait Faik'in Realitesi”, Varlık Dergisi, 407. Say1, Haziran 1954. s. 43.

28 Sait Faik Abasıyanık, Alemdăg'da Var Bir Yılan, Türkiye İş Bankası Kültür Yayınları, İstanbul 2015. s. 8-9. 
kökenine inerek "there is no need of definite code when authority of custom is yet unquestioned" 29 ["geleneğin otoritesinin sorgulanmadıkça belirli bir (ahlâkî) yasanın gereği yoktur"'] der ve ahlak kaidelerinin dini etkenlerden çok sosyolojik etkenlerden hareketle meydana geldiğini belirtir. ${ }^{30}$ Dolayısıyla "hiçbir kitap"ta bulunmayan ve "kilise ahlâkı"ndan farklı olan Sait Faik' in ütopyasındaki ahlakı, yeni bir sosyolojik yapının neticesi olarak, yani insan sevgisinin egemenleştiği bir döneme uygun ahlâk olarak görebiliriz.

Söz konusu ütopyada hayatın her yönüne duyulan olumlayıcı tutumla beliren hususiyet, Sait Faik' in 1953 yılında Şimdi Sevişme Vakti adı altında yayımladığı şiirlerinden "Ceylânı Bahri”de de karşımıza çıkar. Hayat sevincinin dizeleştiği şiirdeki anlatıcı-şairin kendisine sevinç veren bir çocuk vesilesiyle dile getirdikleri, bu bağlamda önemlidir. Anlatıcı-şair;

“Gelecek bir sabah vakti, güneşten;

-Derin elemlere rüzgâr-

Bastonunda kış armutları asılı

Küpeştesinde ekmek ayvaları,

Kirli yelkenine firtınalar sartl

Kavunlarında sulh ve sükûn

Halatlarinda mesut sahillerle

Bir ceylânı bahri. "'31

dizelerinden de anlaşılacağı üzere, gelecekteki mutlu günleri, "gemilerin başındaki direğin ileriye doğru uzanmış kısmı” anlamına gelen “ceylânı bahri”nde ve etrafındaki gemi yüklerinde görerek sembolik bir örüntüye başvurur.

\section{2.Ütopyanın Haritalandırılması ve Ütopyaya Giden Yol}

Sait Faik' in ütopyasıyla ilgili bazı önemli hususiyetlere de, yüzeysel değil, derin bir okumayla; Paul de Man'ın özgün yapıbozumculuk teorisindeki kavramlarla konuşursak, "körlük" ile değil, "içgörü"32 ile ulaşabiliriz. Bu noktada ilk olarak belirtmek gerekir ki; özellikle Sait Faik’in son dönemlerinde kaleme aldığı iki eserinde, yani

29 Evolution of Society, s. 38.

30 A.g.e., s. 39.

31 Sait Faik Abasıyanık, Şimdi Sevişme Vakti, Türkiye İş Bankası Kültür Yayınları, İstanbul 2014. s. 7.

32 Man ve ardılları, edebi eserlerin yoğun bir metaforik üsluba sahip olduğunu, dolayısıyla da söz konusu eserlerin yüzeysel ve derin okumalar karşısında farklı mesajlarla alımlanabileceğini düşünür. Bu bağlamda "körlük" yüzeysel okumanın; "içgörü” ise derin okumanın temel hususiyetidir. Paul de Man, Körlük ve İçgörü: Çağdaş Eleştirinin Retoriği Üzerine Denemeler, Çev. Ferit Burak Aydar-Cem Soydemir, Metis Yayınları, İstanbul 2008. s. 30-31. 
Kayıp Aranıyor romanıyla "Alemdağ'da Var Bir Yılan" hikâyesinde sığınak olarak beliren mekânlar göz önünde bulundurulduğunda, Sait Faik'in ütopyasında bir somutlaşma temayülünün varlığını gözlemleyebilmenin mümkün olduğudur. Bu somutlaşma, aynı zamanda ütopyanın saflığını yitirmesi ve görece küçük hedeflerle varlık kazanması olarak da okunabilir. Bunu, sosyolog Zygmunt Bauman'ın yeryüzünün modern dönemlerde gözlemlenebilir ve ölçülebilirliğini imleyen mekânın haritalandırılmast ${ }^{33}$ tabirinden hareketle ütopyanın haritalandırılması olarak adlandırabiliriz. Bu bakımdan Alemdağ'a yolculuk yapan bir aylağın başından geçenlerin konu edinildiği “Alemdağ'da Var Bir Yılan”da, modern hayatın keşmekeşinin en açık surette belirdiği; "köprüsü balgamlı", "geceleri kusmuklu”, "yan sokakları çamurlu”; hülasa kirli bir İstanbul manzarası karşısında, henüz "İstanbullaşamamış” ve dolayısıyla bozulmamış doğasıyla birlikte aylak kahramanın gözünde sığınak olan Alemdağ'1, ütopyanın somutlaşmış, ete kemiğe bürünmüş, "haritalandırılmış" bir hâli olarak okumak mümkündür:

"Günlerden pazartesi. Yine vapurun alt kamarasındayım. Yine hava karll. Yine İstanbul çirkin. İstanbul mu? Çirkin şehir. Pis şehir. Hele yağmurlu günlerinde. Başka günler güzel mi, değil; güzel değil. Başka günler de köprüsü balgamlıdır. Yan sokakları çamurludur, molozludur. Geceleri kusmukludur. Evler güneşe sırtını çevirmiştir. Sokaklar dardır. Esnafi gaddardır. Zengini lakayttır. Insanlar her yerde böyle. Yaldızlı karyolalarda çift yatanlar bile tek.

Yalnızlık dünyayı doldurmuş. Sevmek, bir insanı sevmekle başlar her şey. Burada her şey, bir insanı sevmekle bitiyor.

Güzel yer, güzel yer Alemdağ. Şu saatte on beş metrelik ağaçlarlyla, Taşdelen'iyle, yılanıyla ... Ama kış günü yılanlar inindedir. Olsun. Hava Alemdağ'da ılıktır. Güneş yaprakları kıpkızıl ağaçların içine doğmuştur. Gökten parça parça ılık bir şeyler yağmakta, çürümüs yaprakların üstüne birikmektedir. Taşdelen parmak gibi akar. Iç̧imizi şıkır şıkır eden bir maşrapayla önce içimizi, sonra çırılçılak soyunarak dışımızı yıkıyor. Su içmeye gelen bir tavşan, bir yılan, bir kara tavuk, bir keklik, Polonezköy'den şerefimize kaçıp gelmiş bir keçiyle alt alta üst üste oynaşıyoruz." ${ }^{34}$

Genç bir kadının mutluluk arayışının kurgulaştırıldığı Kayıp Aranıyor romanında ise Sait Faik'in sığınak olarak somutlaşan mekânı, İstanbul ve Ankara gibi büyük şehirlerin zıttına, insani ilişkilerin "yabancılaşma” ya henüz maruz kalmadığ1 ve doğal nitelikleri yitirilmemiş bir balıkçı köyüdür. Bir yönüyle güçlü bir orta-sınıf eleştirisinin işlendiği romanın baş-kişisi olan Nevin, duyarsızlık duvarlarıyla örülü şehir hayatından bu balıkçı köyüne kaçar. Fakat bu köyün de şehirlerin keşmekeşine yavaş yavaş şahit olunmasıyla -ve Nevin'in kolay "saadet" arayışının hüsranla sonuçlan-

33 Ziygmunt Baumann, Küreselleşme: Toplumsal Sonuçları, Çev. Abdullah Yılmaz, Ayrıntı Yayınları, İstanbul 2014. s. 37-38.

34 Alemdağ'da Var Bir Yılan, s. 24-25. 
ması- sebebiyle sığınak değişir. Nevin, "Türkiye'de bir yere bir tren bileti alarak" 35 ve muhtemelen daha ücra bir Anadolu kasabasını veya köyünü tercih ederek kaçacak; böylelikle de -bir anlamda- sığınak olarak beliren ütopya da burası olacaktır.

Fransız natüralizminin öncülerinden Alphonse Daudet'nin Değirmenimden Mektuplar kitabındaki kahramanın modern hayatın bütün ağırlığının hissedildiği Paris’ten doğal güzelliğini yitirmemiş olan Provence bölgesine kaçışın1 ${ }^{36}$ anımsatan bu iki eserle Sait Faik'in ütopyasında kısmen bir "nitel değişim” yaşandığını ifade edebiliriz. Nitekim bu iki eserde, Sait Faik, daha evvel kaleme aldıklarından farklı bir ütopik dünya kurar gibidir: Doğaya, samimiyete dönük bir dünya.

Peki Sait Faik'in ütopyasındaki bu nitel değişimin sebebi ne olabilir? Şüphesiz bu soru karşısında öne sürülebilirliği olan bir cevap vardır: O da, bu öykülerin yazıldığı sırada iktidarı yeni devralan Demokrat Parti’nin öncülük ettiği hızlı kapitalistleşme sürecinin şehir hayatındaki bariz etkisi sebebiyle yazarın doğal güzelliği daha net bir şekilde kavraması ve onu koruma isteğine tutunmasıdır. Nitekim 1952 yılında yayımlanan ve kitaba ismini veren "Son Kuşlar" hikâyesinde yazar, bu durumu açık bir şekilde kurgusallaştırır ve Berna Moran’ın "belirtik hakikat”37 adını verdiği düzlemde ele alarak şunları söyler:

"Dünya değişiyor dostlarım. Günün birinde gökyüzünde güz mevsiminde artı esmer lekeler göremeyeceksiniz. Günün birinde yol kenarlarında toprak anamızın koyu yeşil saçlarını da göremeyeceksiniz. Bizim için değil ama, çocuklar, sizin için kötü olacak. Biz kuşlarl ve yeşillikleri çok gördük. Sizin için kötü olacak. Benden hikâyesi." ${ }_{38}$

Sait Faik'in ütopyasında “içgörü” ile bakmamız gereken esas husus ise, söz konusu ütopyanın temelinde yatan temel bireysel ve toplumsal süreçlerdir. Eserlerini özellikle İkinci Dünya Savaşı yıllarında ve hemen sonrasında veren Sait Faik’i ütopik bir dünya resmetmeye götüren ve onu Yalçın Küçük'ün "kurgu-red-ütopya" 39 formülüyle ifade ettiği aydın duruşuna yaklaştıran, şüphesiz, yukarıda da belirtildiği gibi, hayata karşı sahip olduğu iyimser bir bakış açısıdır. Bu iyimser bakış açısı, temel olarak, savaş yıkımlarının yarattığı aksülamel olarak okunabilir. Mehmet Kaplan'ın Sait Faik'in "Köprü” şiirini çözümlerken ${ }^{40}$ dile getirdiklerini bu noktada göz önünde

35 Sait Faik Abasıyanık, Kayıp Aranıyor, Türkiye İş Bankası Yayınları, İstanbul 2016. s. 102.

36 Alphonse Daudet, Değirmenimden Mektuplar, Çev. Selin Ceyhan, Alkım Yayınları 2008. s. 3-4.

37 Berna Moran, Edebiyat Kuramları ve Eleştiri, İletişim Yayınları, İstanbul 2007. s. 278.

38 Son Kuşlar, s. 7.

39 Küçük, aydın sınıfının Batı ve Türkiye pratiğine baktığında görebildiği hususiyetleri bu şekilde formülleştirir. Küçük’e göre aydın, Rönesans dönemindeki gibi geçmişi reddeder, yeni bir dünyanın "kurgu"sunu oluşturur ve bunu da ütopik bir şekilde ortaya koyar. Bkz. Yalçın Küçük, Tenkit: Materyalist Gözlerimle Yazarlarımı, Tekin Yayınevi, İstanbul 2016. s. 45.

40 Mehmet Kaplan söz konusu çözümlemede, Sait Faik'in özellikle hikâyelerindeki tabiat akisleri ve sıfatlardan hareketle şunları dile getirir: "Sait Faik, hikâyelerinde, varlıkların ve insanların dış görünüşleri ile bıraktıkları intiba ve ruh hallerini en ince teferruatına kadar gören ve taze bir 
bulundurursak, söz konusu aksülameli anlayabilmek olasıdır. Burada en temel olgu, İkinci Dünya Savaşı karşısında en açık ifadesini André Gide'in Dünya Nimetleri'nde bulan hedonist tutumun -tıpkı o dönem Batı'daki ve Türkiye'deki şair ve yazarlarda olduğu gibi- Sait Faik’te de özellikle hayata dönük sevgi çerçevesinde öne çıkmasıdır.

\section{SONUÇ}

Yazdığı Çehov tarzı realist hikâyelerle modern Türk hikâyeciliğinin önde gelen temsilcileri arasında önemli bir yer edinen Sait Faik Abasıyanık, insana, doğaya ve bir bütün olarak hayata yönelik sevgisiyle bağlantılı bir şekilde, bir ütopyaya; daha doğrusu bir ütopyacı itkiye doğru yönelir. Bu ütopyacı itki, genel olarak eşitlikçiliğin ve insanın merkez alındığı; hayattaki her bir unsurun sevgiyle ele alındığı ve bu minvalde yeni bir ahlak prensibinin egemen kılındığı bir dünya olarak yazarın eserlerinde somutlaşır.

Sait Faik'in ütopyası, özellikle son yazdığg eserlerde, hızla kapitalistleşen Türkiye'de doğa kıyımına karşı gösterilen koruyucu bir tutum dolayısıyla şehirden uzak ve doğal güzelliklerini yitirmemiş, sığınak olarak beliren mekânlarla somutlaşır. Bu somutlaşma ile söz konusu ütopya, görece küçük hedeflerle çerçevelenmiş ve saf hâldeki görkemini yitirmiş olur.

Sait Faik'i bu şekilde bir ütopya kurmaya götüren temel sebepler veya söz konusu ütopyanın altında yatan en belirleyici toplumsal ve bireysel süreçler, şüphesiz yazarın eserlerini verdiği dönemin atmosferinde aranmalıdır. Eserlerin kaleme alındığı dönemde İkinci Dünya Savaşı ve hemen arakasından onun yıkıcı sonuçları bütün dünyada olduğu gibi Türkiye'de de idrak edilir. Bu da bir aksülamel yaratır: Batı' daki yazarlar ve şairler nezdinde olduğu gibi yerli yazarlar ve şairler nezdinde de iyimserliğe doğru yönelen bir hedonizm ve hayat sevgisiyle somutluk kazanan bir aksülamel. Sonuç itibariyle söz konusu toplumsal ve bireysel süreçler, Sait Faik'in ütopyasının oluşumunda rol oynayan temel parametreleri teşkil eder.

üslupla tesbit eden bir sanatkârdır. Türk edebiyatında sıfatları onun kadar maharetle kullanan pek az kimse vardır. Sait'in yazılarında her sıfat, canlı ve müşahhas varlığın bir parçasıdır. Yazar, bahsettiği her şeyi öyle tasvir ve tavsif eder ki, âdeta, onlarla, doğrudan doğruya temas etmiş gibi oluruz. Şiirlerinde de aynı canlılık ve 'doğrudan doğruya'lık vardır. Bu bakımdan onunla Orhan Veli ve Cahit Sıtkı arasında bir yakınlık mevcuttur. Bu üç sanatkâr da duyularla yaşamaya önem veren, 'sensualisme'i bir hayat felsefesi haline getiren André Gide'in tesiri altında kalmışlardır. Aralarındaki benzerlik, belki de, bunun bir neticesidir. Varlıkla doğrudan doğruya teması gaye edinen bu davranış tarzı, insanla varlık arasında bir perde gibi giren kelimeyi âdeta yok eder. Edebiyat dille yapıldığına göre buna imkân yoktur. Bu imkânsızlık karşısında yazar, dili öyle kullanır ki, uyandırdığı intiba kendi varlığını unutturur.” Mehmet Kaplan, Şiir Tahlilleri 2: Cumhuriyet Devri Türk Şiiri, Dergâh Yayınları, İstanbul 2009. s. 134. 


\section{KAYNAKÇA}

Abasıyanık, Sait Faik, Alemdağ 'da Var Bir Yılan, Türkiye İşs Bankası Kültür Yayınları, İstanbul 2015. Abasıyanık, Sait Faik, Havada Bulut, Türkiye İş Bankası Kültür Yayınları, İstanbul 2015. Abasıyanık, Sait Faik, Kayıp Aranıyor, Türkiye İş Bankası Yayınları, İstanbul 2016. Abasıyanık, Sait Faik, Mahalle Kahvesi, Türkiye İş Bankası Kültür Yayınları, İstanbul 2015. Abasıyanık, Sait Faik, Medarı Maişet Motoru, Türkiye İş Bankası Kültür Yayınları, İstanbul 2014. Abasıyanık, Sait Faik, Son Kuşlar, Türkiye İş Bankası Kültür Yayınları, İstanbul 2015. Abasıyanık, Sait Faik, Şahmerdan, Türkiye İş Bankası Kültür Yayınları, İstanbul 2014. Abasıyanık, Sait Faik, Şimdi Sevişme Vakti, Türkiye İş Bankası Kültür Yayınları, İstanbul 2014.

Adorno, Theodor W.-Horkheimer Max, Aydınlanmanın Diyalektiği, Çev. Nihat Ülner-Elif Öztarhan Karadoğan, Kabalcı Yayınları, İstanbul 2000.

Althusser, Louis, İdeoloji ve Devletin İdeolojik Aygıtları, Çev. Alp Tümertekin, İthaki Yayınları, İstanbul 2014.

Bahar, Halil İbrahim, Sosyoloji, USAK Yayınları, Ankara 2005.

Bauman, Zygmunt, Küreselleşme: Toplumsal Sonuçları, Çev. Abdullah Yılmaz, Ayrıntı Yayınları, İstanbul 2014.

Brown, J.A.C., Evolution of Society, Watts \& Co., London, 1946.

Daudet, Alphonse, Değirmenimden Mektuplar, Çev. Selin Ceyhan, Alkım Yayınları 2008.

de Man, Paul, Körlük ve İçgörü: Çağdaş Eleştirinin Retoriği Üzerine Denemeler, Çev. Ferit Burak AydarCem Soydemir, Metis Yayınları, İstanbul 2008.

Foucault, Michel, Büyük Kapatılma, Çev. I. Ergüden-F.Keskin, Ayrıntı Yayınları, İstanbul 2007.

Hançerlioğlu, Orhan, Düşünce Tarihi, Remzi Kitabevi, İstanbul 2011.

Jameson, Fredric, Modernizm İdeolojisi: Edebiyat Yazıları, Çev. Kemal Atakay-Tuncay Birkan, Metis Yayınları, İstanbul 2008.

Jameson, Fredric, Ütopya Denen Arzu, Çev. Ferit Burak Aydar, Metis Yayınları, İstanbul 2009.

Kaplan, Mehmet, Şiir Tahlilleri 2: Cumhuriyet Devri Türk Şiiri, Dergâh Yayınları, İstanbul 2009.

Küçük, Yalçın, Tenkit: Materyalist Gözlerimle Yazarlarımız, Tekin Yayınevi, İstanbul 2016.

Livaneli, Zülfü, Gözüyle Kartal Avlayan Yazar: Yaşar Kemal, Doğan Kitap, İstanbul 2016.

Marx, Karl-Engels, Fredrich, Collected Works, Vol. 3, Lawrance and Wishart, London 1975.

Moran, Berna, Edebiyat Kuramları ve Eleştiri, İletişim Yayınları, İstanbul 2007.

Politzer, Georges, Felsefenin Temel İlkeleri, Çev. Erol Esençay, İlya İzmir Yayınevi, İzmir 2008.

Tanpınar, Ahmet Hamdi, “Türk Edebiyatında Cereyanlar", Edebiyat Üzerine Makaleler, Haz. Zeynep Kerman, Dergâh Yayınları, İstanbul 1990.

Ürgüp, Fikret, "Sait Faik'in Realitesi”, Varlık, 407. Sayı, Haziran 1954. 